\title{
Political Dimensions of the Northern Afghanistan Resupply Routes
}

\author{
Gregory Gleason *
}

A series of insurgent attacks in Pakistan targeting U.S./NATO supply lines took place during the latter half of 2008 and early 2009. As much as 75 percent of the cargo to support military operations and development programs in Afghanistan previously had been shipped through Pakistan, passing through a small number of precarious transport corridors, constrained by chokepoints and subject to disruption. As a result of insurgent attacks, carriage of supplies through the Khyber Pass along the Pakistan-Afghanistan border was repeatedly interrupted for brief periods. These events in Pakistan shifted Allied attention from the southern routes to Afghanistan's northern access routes. The existing transit routes for supplies entering Afghanistan from the north passed across European and Eurasian countries and then through the Central Asian countries. This combination of port, air, rail, and road facilities came to be referred to within the framework of Afghanistan's normalization operations as the NDN - the "Northern Distribution Network."

The significance of the shift of attention from the southern supply routes to the NDN was dramatically underscored by the Kyrgyz government's announcement in early February 2009 of their rescission of landing rights at the Manas airbase near Bishkek, Kyrgyzstan. ${ }^{1}$ The Manas airbase had been playing a vital role as a key northern transit node, particularly for NATO-ISAF ${ }^{2}$ and U.S. Operation Enduring Freedom $(\mathrm{OEF})^{3}$ soldiers on their way to and from Afghanistan. The Kyrgyz government's decision raised alarm regarding the reliability of the United States' re-

Gregory Gleason is a professor of political science and public administration at the University of New Mexico. He also serves as a professor of Eurasian Security Studies at the George C. Marshall European Center for Security Studies, where he is a seminar leader for the Center's Program for Advanced Security Studies.

1 Gregory Gleason, “Kyrgyzstan's Multivector Foreign Policy Unravels,” Radio Free Europe / Radio Liberty Commentary (11 February 2009).

2 The International Security Assistance Force (ISAF) is a NATO-led security and stabilization effort in Afghanistan. ISAF was outlined by the Bonn Agreement of December 2001 and formally established by the United Nations Security Council Resolution 1386 of 20 December 2001, and was expanded by Security Council Resolution 1510 of 13 October 2003.

3 Operation Enduring Freedom (OEF) primarily consists of the U.S. military operation in Afghanistan under the control of U.S. Central Command. While OEF is primarily focused on Afghanistan operations, it also addresses the effort to combat terrorism. OEF was organized as one of two overseas contingency operations that, beginning in fiscal year 2010, will subsequently be administered through the Department of Defense annual budget rather than as a supplemental appropriation from Congress. 
gional partners in the effort to stabilize and normalize Afghanistan, provoking considerable commentary and speculation over the sustainability of the NDN. ${ }^{4}$

By mid-2009, the risk to the NDN had been overcome by agile diplomacy. Two factors stood out. The first was series of new, bilateral agreements between the U.S. and the Eurasian countries that provided for the transport of supplies necessary for ISAF and U.S. normalization operations in Afghanistan. ${ }^{5}$ The second was the decision of the government of Kyrgyzstan in July 2009 to establish a new "Manas Transit Center," taking the place of the U.S. military base. ${ }^{6}$ The agreements were announced by U.S. Under-Secretary of State for Political Affairs William Burns, following meetings with political leaders in the Central Asian states and in Russia in early July 2009. The agreements reflected a broad consensus among the Eurasian countries regarding the stakes involved for the region in Afghanistan's normalization.

The diplomatic initiatives in the Eurasian countries represented a significant change in U.S. policy. By mid-2008 there was a general recognition that the stabilization efforts in Afghanistan as then constituted were insufficient. The Bush Administration initiated a major strategic policy review, but the outcome was delayed to some extent by the presidential elections in the U.S. As State Department documents indicate, terrorist attacks in Afghanistan rose dramatically during the period from 2005 to 2008, as shown below in Table $1 .^{7}$

A September 2008 UN Special Report on Afghanistan noted that insurgent actions expanded during the previous year, reliance on asymmetric insurgent tactics sharply rose, violent cross-border activities from Pakistan increased significantly in terms of numbers and sophistication, civilian deaths as a result of military operations carried out by Afghan and international security forces increased, and

4 See, for instance, the argument that "Washington's reliance on Central Asia shows how few options it has in its Afghanistan campaign. The region is a seriously risky bet." Paul QuinnJudge, "The Risk to U.S. Supply Lines," The Wall Street Journal (11 March 2009). Also see "Road Blocks: No Easy Routes into Afghanistan," The Economist (5 March 2009); available at www.economist.com/world/asia/displaystory.cfm?story_id=13240686. Also see STRATFOR, "Special Report: U.S.-NATO, Facing the Reality of Risk in Pakistan"; available at www.stratfor.com/analysis/20090424_pakistan_facing_reality_risk_pakistan.

5 The willingness to ensure open transportation corridors was first formally proposed by Uzbek President Islam Karimov at the April 2008 NATO meeting in Bucharest, Romania. Following U.S. requests, statements of assent to open corridors were made by Eurasian political leaders throughout the region, culminating in Russian President Medvedev's statement in July 2009. See Roger McDermott, "Medvedev Expands the Northern Supply Route to Afghanistan," Eurasia Daily Monitor, Jamestown Foundation (7 July 2009).

6 "New Deal on U.S. Air Base in Kyrgyzstan Signed into Law," Radio Free Europe / Radio Liberty (7 July 2009); available at www.rferl.org/articleprintview/1771114.html

7 See U.S. State Department, Country Reports on Terrorism 2008, Office of the Coordinator for Counterterrorism (April 2009), 348; available at www.state.gov/documents/organization/ 122599.pdf. 
Table 1: Terrorist Incidents in Afghanistan.

\section{$\begin{array}{llll}2005 & 2006 & 2007 & 2008\end{array}$}

Terrorist attacks in Afghanistan

494

968

1125

1220

Attacks resulting in at least one death, injury, or kidnapping

369

694

890

948

People killed, injured, or

kidnapped as a result of

1,551

3,556

4,662

terrorism

violent attacks on foreign assistance-related targets and non-governmental organizations had become more frequent and more deadly. ${ }^{8}$ In a foreboding assessment of the war's progress, America's highest-ranking soldier, Admiral Michael Mullen, the Chairman of the U.S. Joint Chiefs of Staff, told the U.S. House Armed Services Committee in September 2008, "I am not convinced that we are winning ... in Afghanistan." 9 There were competing opinions regarding the future; some argued that the situation called for a withdrawal of forces, while others argued that perseverance was the appropriate response. ${ }^{10}$

It was in this context that a new U.S. administration took office in January 2009. But even before the Obama Administration came into power, it was clear that one of the administration's first priorities was the recalculation of U.S. policy

8 UN Security Council, "The Situation in Afghanistan and its Implications for International Peace and Security: Report of the Secretary-General," A/63/372-S/2008/617 (23 September 2008), 2; available at www.globalpolicy.org/security/issues/afghan/2008/0923reportban.pdf.

9 Ann Scott Tyson, "Top Military Officer Urges Major Change in Afghanistan Strategy," Washington Post (11 September 2008): A01.

10 A recent report of the International Crisis Group asserted: "Withdrawing international troops with the threat that any regrouping of jihadist or [Al Qaeda] can be countered by air power and special forces would simply return the country to the control of jihadist. Air power has not proven successful against insurgents or terrorist bases. Neglect would allow the region to descend into further chaos, as it did in the 1990s." In contrast, in a Carnegie Endowment study, Gilles Dorronsoro argued, "The only meaningful way to halt the insurgency's momentum is to start withdrawing troops. The presence of foreign troops is the most important element driving the resurgence of the Taliban." International Crisis Group, "Afghanistan: New U.S. Administration, New Directions," Asia Briefing No. 89 (Kabul/Washington/ Brussels, 13 March 2009), 3; available at www.crisisgroup.org/home/index.cfm. Gilles Dorronsoro, Focus and Exit: An Alternative Strategy for the Afghan War (Washington, D.C.: Carnegie Endowment for International Peace, January 2009), 2; available at www.carnegieendowment.org/publications. 
toward Afghanistan. The administration's strategic review resulted in the March 2009 announcement by President Obama that the U.S. was facing an increasingly perilous situation. U.S. strategy toward Afghanistan was motivated first and foremost, President Obama explained, by the need to protect the American people from extremist violent threats. Obama stressed that the U.S. had limited objectives: "We are not in Afghanistan to control that country or to dictate its future. We are in Afghanistan to confront a common enemy that threatens the United States, our friends and our allies, and the people of Afghanistan and Pakistan who have suffered the most at the hands of violent extremists."11 President Obama also drew attention to the close interaction between events in Pakistan and Afghanistan, stating: ${ }^{12}$

The ability of extremists in Pakistan to undermine Afghanistan is proven, while insurgency in Afghanistan feeds instability in Pakistan. The threat that Al Qaeda poses to the United States and our allies in Pakistan-including the possibility of extremists obtaining fissile material-is all too real. Without more effective action against these groups in Pakistan, Afghanistan will face continuing instability.

Recognizing the close interaction between events in Pakistan and Afghanistan, Obama explained, "The core goal of the U.S. must be to disrupt, dismantle, and defeat Al Qaeda and its safe havens in Pakistan, and to prevent their return to Pakistan or Afghanistan."

The gathering of Afghan, Pakistani, and U.S. officials in the Trilateral Consultations that took place in Washington in May 2009 represented the first major foreign policy initiative in the Obama Administration's new strategy for Afghanistan. President Asia Ali Zadora of Pakistan and President Hamid Karzai of Afghanistan met with U.S. President Barack Obama in advance of staff meetings covering a broad spectrum of political, economic, and military issues. These meetings marked the beginning of an effort to initiate a qualitatively new level of regional policy coordination in South Asia. U.S. Secretary of State Hillary Clinton, emphasizing "defense, development, and democracy" as the triad uniting the governments' goals in sponsoring regional cooperative relationships throughout South Asia, referred to the outcome of the Trilateral Consultations as a "work plan," representing more of a process than an act. The parties signed a memorandum of understanding in which they pledged to work together toward the conclusion of a trade transit agreement before the end of the year. A Pakistan-Afghani-

11 "Remarks by the President on a New Strategy for Afghanistan and Pakistan" (Washington, D.C.: The White House, 27 March 2009); www.whitehouse.gov/the_press_office/Remarksby-the-President-on-a-New-Strategy-for-Afghanistan-and-Pakistan/.

12 See "White Paper of the Interagency Policy Group's Report on U.S. Policy toward Afghanistan and Pakistan," available at www.whitehouse.gov/assets/documents/AfghanistanPakistan_White_Paper.pdf. 
stan Transit Agreement has long been sought as a means of promoting not only bilateral trade but also as a bridge to greater regional trade integration that would serve to move Afghanistan out of the category of a "landlocked" country to a "land-linked" country.

Washington's new approach is rooted in the recognition that the speed and sustainability of reconstruction in Afghanistan is in part dependent upon the reintegration of Afghanistan into the international community. Reintegration, in turn, is dependent upon the capability to promote Afghanistan's trans-border linkages of communication, trade, transport, water, power, and investment. The first step in all of these functions is transport. Materials, technology, expertise, and market access all require transportation. But precisely because it is reintegration that is the necessary first stage of normalization and stabilization in Afghanistan, it is also the point of greatest vulnerability. That which can be supplied in order to assist reintegration can also be denied in order to manipulate or damage the process. To the extent that adaptive insurgents will seek to evade, seek to escalate, and seek to spoil, the Allies' new reliance upon the NDN presents a number of distinct risks.

Russia, the Eurasian countries, and the Central Asian countries have all agreed to facilitate the movement of non-lethal supplies and materiel through the northern route to aid in Afghanistan's normalization and reconstruction. But this raises real questions regarding the extent to which the dependence of NATO and the U.S. on the unimpeded carriage of supplies places Western allies in a potentially compromising position. What would be the risks involved? To the extent that the continued cooperation of the Eurasian countries is a critical element in the successful prosecution of the Afghanistan war effort, the political dimensions of the northern resupply routes to Afghanistan deserve considerable attention. The transportation routes reach across a number of different countries with foreign policy objectives that are sometimes at variance with one another. To what extent is the physical transportation system itself a factor in international regional cooperation?

\section{“NDN”: The Northern Distribution Network and Eurasian Transit Corridors}

Major freight transport takes place via four forms of conveyance: ship, rail, road, and air. Maritime transport is the least expensive, rail the next most affordable, followed by road. Air is by far the most costly. Because Afghanistan is landlocked, maritime transport can only be used for a portion of the journey. Rail and road conveyance also involve loading and transfers, which are both expensive and cumbersome. Seamless freight is shipped across a variety of modes of conveyance with a minimum of delay and minimization of the costs associated with inter-modal connections, which use roll-on/roll-off or container traffic. Containerization 


\section{South and Central Asian Infrastructure Initiatives}

- TRACECA (details at www.unescap.org/ttdw/index.asp)

Transport Corridor Europe-Caucasus-Asia

The TRACECA Program was launched at a conference in Brussels in May 1993 as an intergovernmental initiative initially financed by EU technical assistance funds. TRACECA was formalized with the adoption of the "Basic Multilateral Agreement on International Transport for Development of the Europe-Caucasus-Asia Corridor," which was ratified in Baku on 8 September 1998.

- ESCAP-Transport (details at www.unescap.org/ttdw/index.asp)

UN Economic and Social Commission for Asia and the Pacific-Transport Division

The United Nations Economic and Social Commission for Asia and the Pacific (ESCAP) is the regional development arm of the United Nations for the Asia-Pacific region.

- CAREC (details at www.adb.org/carec/)

The Central Asia Regional Economic Cooperation

CAREC is a project financed by the Asian Development Bank focused on financing infrastructure related to energy and transport, trade policy, and trade facilitation. CAREC serves as an alliance of multilateral institutions engaged in promoting economic cooperation.

has overcome the historical problem of the lack of interoperability of Russia's traditional broad gauged rail system with the European and Asian systems.

The geometry of Afghanistan's transport situation is not complicated. There are basically two corridors: the southern and the northern. The southern corridor runs through Pakistan, which is situated located on the southern and eastern borders of Afghanistan. The northern corridor runs through the Central Asian and Eurasian countries located to the north of Afghanistan. In addition to these two main corridors, there is also a road linking Herat, located in northwestern Afghanistan, with Mashhad, in northeastern Iran. There is no rail route entering Afghanistan, and there is no functioning rail line inside Afghanistan by which freight can be transported to the capital and other major cities. So freight delivered by land in Afghanistan is delivered by truck. 


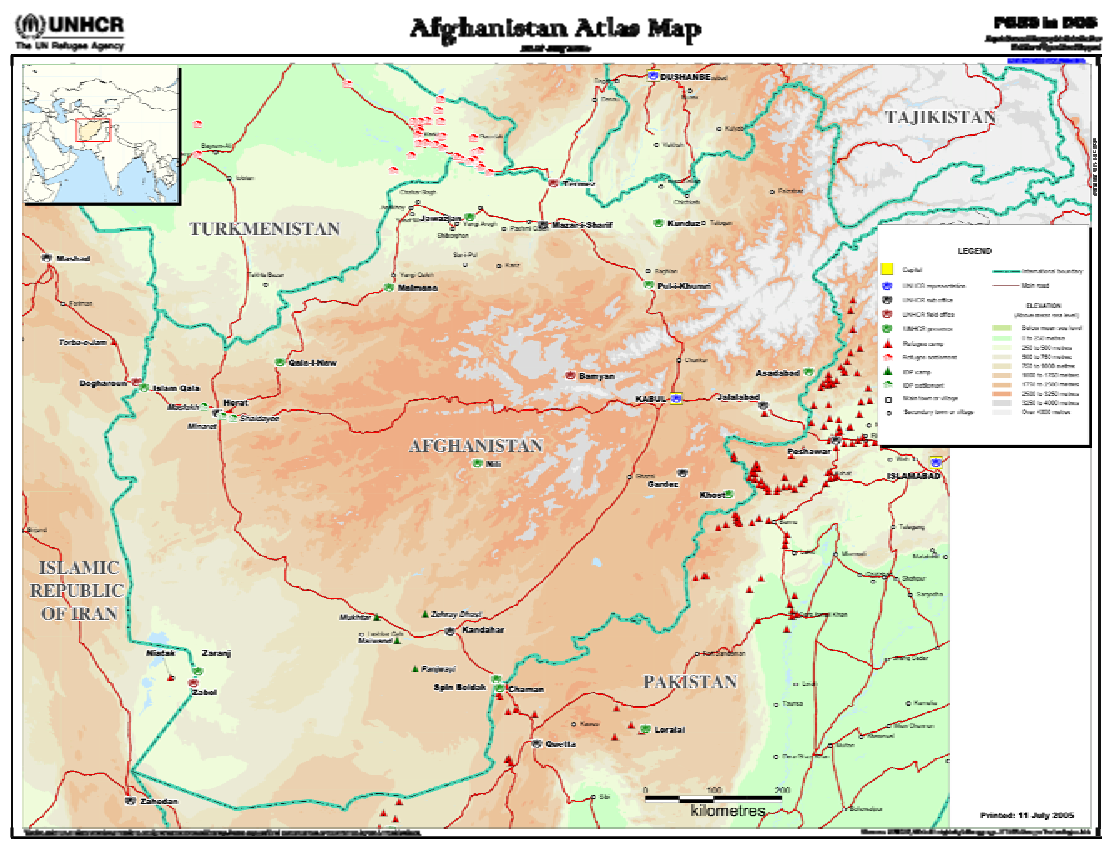

Figure 1: Geography of Afghanistan. ${ }^{13}$

The southern corridor was responsible in the past for roughly 80 percent of freight entering Afghanistan. Maritime freight is delivered to Pakistan through the port at Karachi. Freight destined for Afghanistan is then transported either by road or rail to Quetta or Peshawar. From this point on freight is transported by road. The most heavily relied upon road transport route goes through eastern Pakistan and then through the Khyber Pass into Afghanistan.

The northern corridor involves a number of transit points on Afghanistan's northern border. Tajikistan, Turkmenistan, and Uzbekistan share the border. Rail and road connections from Turkmenistan end at Serhetabat (formerly Kushka) near the Afghan border. Uzbekistan rail and road connections link with Afghanistan through a bridge, financed by the U.S. government and opened in August 2007. The bridge is at the Tajik city of Nizhni Pyanj, connecting freight with the northern Afghanistan city of Kheyrabad. Nizhni Pyanj is located about fifteen kilometers east of the Uzbek city of Termer. Termer served as the main transit point for freight during the period of Soviet military occupation of Afghanistan (1979-89).

13 United Nations High Commission on Refugees (11 July 2008). 


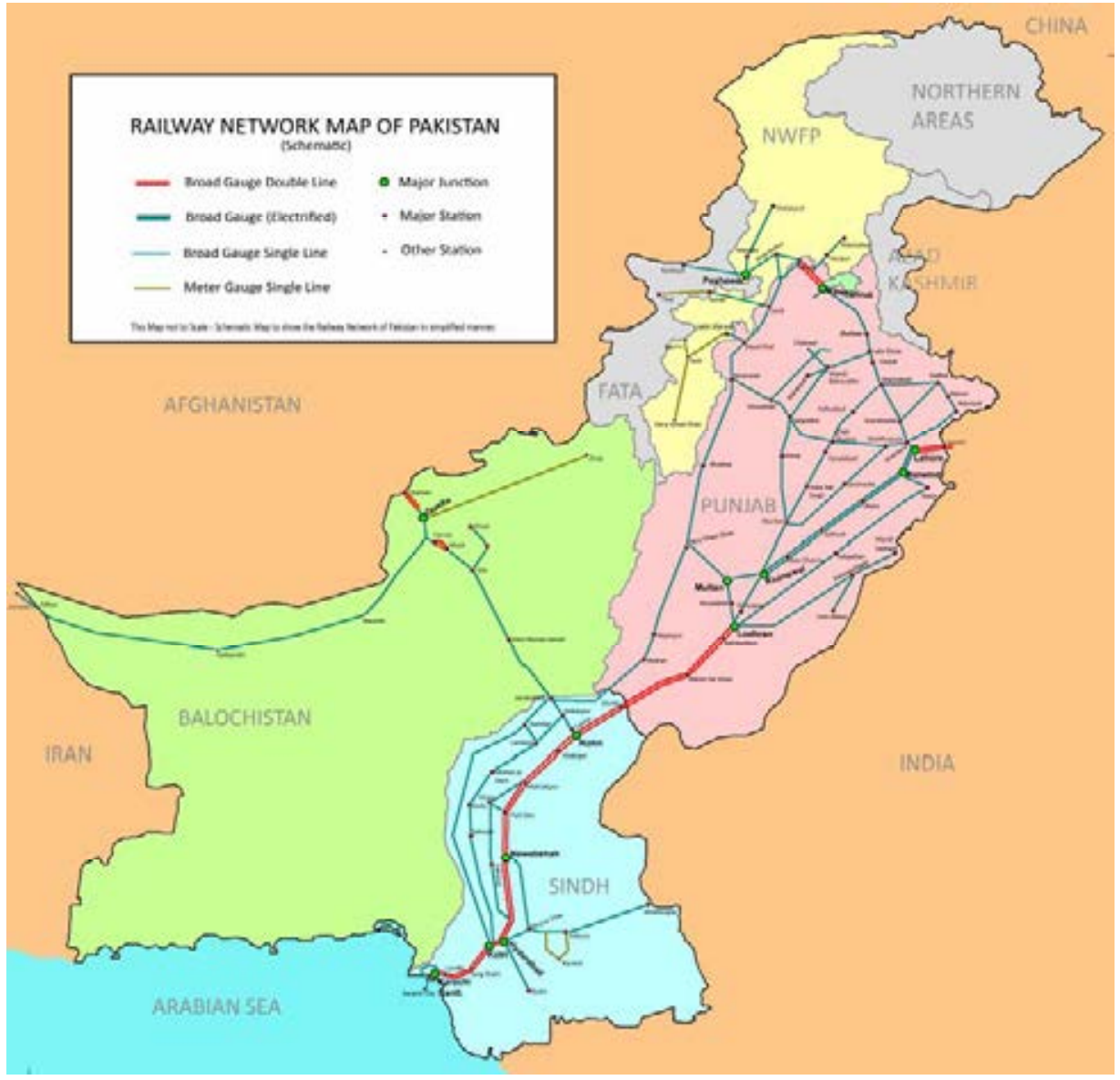

Figure 2: Rail Networks inside Pakistan.

The physical infrastructures of Eurasia - the roads, bridges, airports, railroads, pipelines, waterways, seaports, electrical grids, and telecommunication systemscontinue to shape the patterns of commerce and movement throughout the Eurasian land mass. The influence of these public infrastructures is particularizing and isolating, hindering trade and development and creating great obstacles for cooperation across the region. Rail connections in these countries connect to the rail system that dates from the Tsarist period. The road and rail infrastructure developed during the Soviet period was basically organized on a centrist model, with transport spokes radiating out from Moscow. The fixed infrastructure was not well configured to promote regional trade and development, and even less well config- 


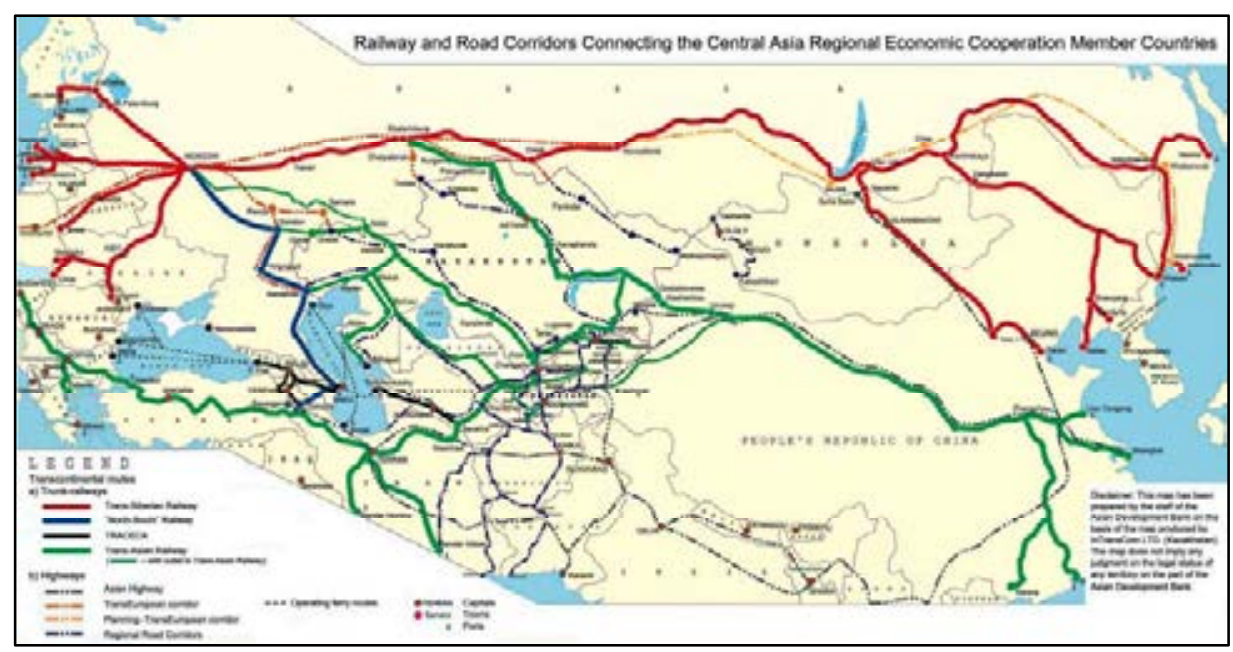

Figure 3: Rail and Road Corridors Connecting Eurasia and Central Asia. ${ }^{14}$

ured to promote trade beyond the former Soviet border with Central Asian, Afghanistan, and South Asian partners.

Russia's rail system has also undergone substantial reform since the Soviet era, with sharply increased interest in serving as a means of integrating Russia into the world economy. The Russian government began the reform of the state rail monopoly in 2000, eventually transforming it into a state-owned joint stock company, Russian Railways JSC, in September 2003. Russian Railways has aggressively sought to expand its commercial interests through foreign infrastructural investments, forming joint ventures with Algeria, Libya, Iran, and Saudi Arabia. Russian Railways has taken over management responsibilities for the Armenian rail network. In 2004, the company finished a rail spur linking the Caspian port of Olay (near Astrakhan) with Russia's main rail network, completing a link in the NorthSouth International Transport Corridor (ITC). In June 2007 a joint venture was established, Eurasia Rail Logistics (ERL), with participation of railway companies from Germany, Poland, and Belarus (Russian Railways holds 30 percent of the company). Russian Railways has made an exceptional effort to shift to containerization, upgrading existing container facilities and constructing new ones to help speed European and Baltic transit. Containerized transit upgrades are designed to provide for rapid and reliable transport along uninterrupted transit routes, including the "Mercury" (Kaliningrad / Klaipeda-Moscow), the "Northern Lights" (Finland-Moscow), the "East Wind" (Berlin-Warsaw-Minsk-Moscow), and the

14 Prepared by the Asian Development Bank. 
"Mongolian Vector" (China-Mongolia-Russia-Belarus-Poland-Germany). The Kaliningrad-Moscow $(1288 \mathrm{~km})$ connection requires only fifty hours, a tremendous improvement over previous service.

During the initial years after the breakup of the Soviet Union in 1991, the former Central Asian republics countries suffered severe economic recession. The transportation infrastructure was deprived of investment for maintenance and improvement. The increase in global production sharing, the reliance on "just in time" product delivery, the shortening of product life cycles, and the increase in global competition have increased the global economy's reliance on timely and responsive infrastructure, and have reduced the economic utility of relatively underdeveloped infrastructure. Even though the economies of the Central Asian countries turned around in the late 1990s and the volumes of freight and passenger traffic significantly increased, the physical transportation infrastructure in these countries remained basically an extension of the previous form.

The greatest challenge of the NDN is not the limited road and rail access from the north, however, but the complications of transit through the Central Asian and Eurasian states. Freight traveling through Uzbekistan to Afghanistan must first be shipped by rail or road through other states. Trans-Caucasus and trans-Russian routes invariably involve considerable logistical complexities, including customs clearance and scheduling problems.

The shift in ISAF/U.S. operational reliance on the NDN has proceeded swiftly, and is showing signs of success. The commanding officer responsible for the establishment of the transportation network explained to the U.S. Congress: ${ }^{15}$

This year, establishing the Northern Distribution Network (NDN), alternative routes to Afghanistan through the Caucasus and Central Asia, has become a high priority. And we have made significant progress in partnership with the Department of State (DOS), DOD, USCENTCOM, U.S. European Command (USEUCOM), and U.S. Pacific Command (USPACOM) to establish these new routes. The NDN-along the historic Silk Road-will leverage the existing commercial distribution networks to move non-military commercial cargo using our U.S. Flag commercial carriers. The NDN also provides additional cargo throughput capabilities vital to support the increasing forces in Afghanistan.

U.S. diplomatic and military officials have repeatedly underscored the importance of the northern transportation corridor for the safe and reliable movement of troops, supplies, provisions, and fuel.

The success of cooperation in Eurasia, Central Asia, and South Asia may be less a physical problem than an administrative and perhaps a political challenge. Continued success depends upon the willingness of the states in these regions to

15 General Duncan J. McNabb, USAF Commander, United States Transportation Command, "Statement Before the House Appropriations Committee, Defense Subcommittee, on the State of the Command" (5 March 2009). 
refrain from one-upmanship in attempting to exploit the vulnerabilities of their neighbors. As Ali Jalali argued, "Despite the presence of international military forces in Afghanistan and the stated commitment of the United States, United Kingdom, and NATO to uphold the independence, territorial integrity, and sovereignty of Afghanistan, the country is still vulnerable to those neighbors' influence, and that has the potential to either spoil or promote Afghanistan's development." 16 Regional cooperation throughout Eurasia may be at the critical moment.

\section{Afghanistan's Northern Neighbors}

The Central Asian countries-Kazakhstan, Kyrgyzstan, Tajikistan, Turkmenistan, and Uzbekistan - have much in common. But they also have important differences, which are reflected in their varying foreign policy postures. The countries in the region are linked by common traditions, common cultures, and closely related languages. In a certain sense, the borders that were drawn in Central Asia were utterly artificial. While the Central Asian peoples had occupied their lands for millennia, no contemporary Central Asian state ever existed in its present borders prior to the Soviet period. Following the Soviet collapse in 1991, the new states of Central Asia were relatively open and collaborative with respect to regional policies. ${ }^{17}$ But by 1993, the countries began shaping new, independent, and sometimes differing foreign policies. These differences continue to be reflected in the strategies developed in each of the individual states.

\section{Kazakhstan}

Kazakhstan's objectives and capabilities defined what could be described as a proglobalization strategy. Kazakhstan emerged from the USSR with a deliberate goal of establishing a democratic system and a market-oriented economy. Kazakhstan's status as a nuclear power, its oil and mineral wealth, its enthusiasm for structural reform, and its mixed Kazakh and Russian populations were defining influences in the domestic political context of foreign policy making during the first years of independence. Kazakhstan's integration into the fabric of international institutions proceeded more swiftly and more fully than did that of its neighbors. The thencapital city of Almaty quickly became the most significant diplomatic center in the region, home to embassies from all the major countries of the world, and the regional offices of many international organizations and multinational companies.

During the first years of the tenure of Kazakhstan's president, Nursultan Nazarbayev, diplomatic efforts were consistently associated with the concept of

16 Ali A. Jalali, “The Future of Afghanistan," Parameters 36:1 (Spring 2006): 4-19 (quoted passage at p. 17).

17 Martha Brill Olcott, “Central Asia's Catapult to Independence,” Foreign Affairs 71:3 (1992): 108-30. 
"Eurasian-ness" - that is, the idea of the close linkages among the peoples of the Central Eurasian landmass. Based on the idea of "Eurasian integration," Kazakhstan's foreign policy followed a careful line, balancing interests based upon many factors. Balancing interests implied not turning away from Russia while at the same time not permitting Russia to dominate decision making for Kazakhstan. For Kazakhstan, this meant maintaining a balanced distance from Russia, remaining neither too close nor too distant. Maintaining good relations with the West and with international organizations was an ideal instrument for achieving what Kazakh policy makers eventually began to refer to as Kazakhstan's "multi-vector" foreign policy. A primary motive (and perhaps the primary motive) for Kazakhstan's globalization policy was the goal of preventing the reemergence of Russian domination in the region.

\section{Tajikistan}

Tajikistan was the smallest, poorest, and most geographically constrained country of the Central Asian region. Tajikistan would likely also have moved swiftly in the direction of post-Soviet reform initially if the country had not fallen victim to an internal contest for power in its first year of independence, which plunged the country into civil war. Tajikistan is a landlocked, mountainous country lacking good transportation routes to the outside world. The war resulted in a blockade by its neighbors, putting further pressure on the already collapsing Tajikistan economy. CIS peacekeeping forces succeeded in stabilizing the country under the leadership of Emomali Rahmon, who was well disposed toward Moscow. The Moscow-Dushanbe compact continued to be an irritant with neighboring Uzbekistan for several years, blocking improvement in relations between Moscow and Tashkent. Tajikistan's struggling legal economy was based almost exclusively on a few mammoth Soviet-era enterprises, such as the Turzonzade aluminum smelter and the Vaksh cascade hydroelectric stations.

\section{Turkmenistan}

Turkmenistan's foreign policy goals soon after independence became closely tied to the personal goals of the country's leader, who adopted the moniker "Saparmurad Niyazov Turkmenbashi the Great." Niyazov adopted an assertive posture of national self-reliance based on Turkmenistan's natural gas revenues. Niyazov eventually came to refer to his policy as one of "positive neutrality." ${ }^{18}$ In practice, the policy meant three things. First, Turkmenistan sought to maintain as much distance as possible from Russia without giving up the big Russian gas market and, most of all, without surrendering access to Western gas markets that, by vir-

18 See Luca Anceschi, "Positive Neutrality: The Role of Foreign Policy in the Consolidation of the Turkmen Regime (1992-2005)," Ph.D. Thesis, La Trobe University, Melbourne, Australia (2006). 
tue of the possession of the fixed pipeline system, Russia in large measure continued to control. Second, it meant wary policies of self-interest with Turkmenistan's Central Asian and Caucasus neighbors. Third, it meant drawing in foreign investment to whatever extent possible to revitalize the gas-related industry and build a Kuwait-style emirate in Turkmenistan.

When Turkmenistan's self-imposed isolation-conceived of as a policy of selfreliance - proved unsuccessful, Turkmenbashi reversed his position 180 degrees. He began championing positive neutrality as the rationale for reestablishing close and friendly relations with Russia. Turkmenbashi then proceeded to conclude a twenty-five-year marketing contract with Russia's towering natural gas monopoly, Gazprom. Turkmen officials who expressed qualms over the contradictions in this policy were removed from positions of influence, usually by accusations of corruption followed by prison sentences. When Turkmenbashi died in late December 2006, a close aide, Gurbanguly Berdymukhamedov, assumed authority and then managed to arrange a legitimizing election naming him president. Berdymuhamedov oversaw a cautious, gradual consolidation of power. He took office with promises of honoring the contractual commitments of the previous government. A series of commercial consultations with Russia and Kazakhstan have led to the construction of a pipeline from Turkmenistan to Russia, via Kazakhstan.

\section{Uzbekistan}

Uzbekistan plays a pivotal role in Central Asia, given its physical location in the heart of the region. Uzbekistan is the only Central Asian country that borders all the other Central Asian countries, located at a convergence point for energy, water, and transportation infrastructure. Uzbekistan quickly established itself as defiantly nationalist after gaining independence. In a few short years the country jettisoned the entire legacy of seventy years of Soviet (and thus, essentially, Russian) political control and cultural influence. Uzbekistan's heavy-handed president, Islam Karimov, who had been a dutiful Communist in his Soviet-era incarnation, soon became an enthusiastic champion of an independent political path, and promoted a thoroughgoing Uzbek cultural renewal. ${ }^{19}$ In ways reminiscent of Turkey's Kemal Ataturk, Karimov engineered a determined national consolidation, a new "Uzbek path." Government, economics, culture-essentially the entire spectrum of public policy and private enterprise - was harnessed in a drive to "recover" Uzbekistan.

After the events of 11 September 2001, Uzbekistan formed a strategic partnership with the United States in order to aid in ousting the Taliban from Afghani-

19 Islam Karimov's justification of his government's policy is presented in his Uzbekistan on the Threshold of the Twenty-first Century (New York: St. Martin's Press, 1998). 
stan. ${ }^{20}$ But this partnership came with a host of conditions relating to standards of practice, governance, and civil rights. After chafing at insistent reminders from U.S. officials over civil rights and the right of free association, Uzbekistan reversed its position, abandoning the U.S. partnership and tilting toward closer relations with Russia. ${ }^{21}$ The opprobrium that had been heaped on Russia for years in Uzbekistan turned virtually overnight into songs of praise. After signing the agreement to join the Eurasian Economic Community, Karimov proudly proclaimed that the reestablishment of close relations with Russia went beyond mere cooperation. He said the new relationship was akin to restoring "union relations," an expression clearly meant to hearken back to the Soviet period.

In terms of coalition and alliance policies since 1991, Uzbekistan has zigzagged in a contradictory pattern, repeatedly proposing cooperative endeavors with competing neighbors and partner states, undercutting diplomatic initiatives with a number of partners. Uzbekistan's political compass indicator has repeatedly shifted orientation, first dramatically shifting away from its northern neighbors, then toward partners in the West, then back to northern partners; now the Uzbek government is apparently seeking new alignment partners. During this period, major institutional arrangements were significantly affected, as Uzbekistan was a founding member of the CIS; provided the venue for the negotiation of the Collective Security Treaty (which later became the CSTO); joined the Central Asian Organization (CAO); withdrew from the CAO; joined GUUAM (aligning in some respects with Georgia, Ukraine, Azerbaijan, and Moldova); forged rapid and close military cooperative arrangements with the U.S. in providing base support for Operation Enduring Freedom (OEF); and then in 2005 switched tack, joining the Kazakh and Russian-led Eurasian Economic Community (Eurasec), the Shanghai Cooperation Organization (SCO), and revitalizing its commitment to the CSTO. In September 2007, Karimov explained a new plan to a somewhat surprised Russian President Medvedev to merge Eurasec and the CSTO in order to form a powerful economic-political "counterweight to NATO." The Russian leaders initially reacted coolly to the Uzbek proposal, basically shelving the idea. Then Russian leaders shifted course in August 2008 in the wake of the five-day Russo-Georgian

20 Shahram Akbarzadeh, Uzbekistan and the United States: Authoritarianism, Islamism and Washington's Security Agenda (London: Zed Books, 2005).

21 In a specific legal sense, Uzbekistan did not "abandon the U.S. strategic partnership." The Memorandum of Understanding that established this relationship still has not been officially nullified and, consequently, continues to remain in force. On the background of U.S.-Uzbek relations, see John Daly, Kurt Meppen, Vladimir Socor, and S. Frederick Starr, Anatomy of a Crisis: U.S.-Uzbekistan Relations, 2001-2005, Silk Road Paper (Washington, D.C.: Central Asia-Caucasus Institute \& Silk Road Studies Program, Johns Hopkins University, February 2006). 
war, seeking to form a broad "post-Soviet consensus" designed to drive a wedge into European security cooperation.

\section{Kyrgyzstan}

Kyrgyzstan's foreign policy was limited by the country's modest resource base and internally divided political situation. After independence, Kyrgyzstan quickly developed a reputation for being the most pro-reform country in the Central Asia region. It was the first post-Soviet country to follow the advice of the international donor community and withdraw from the ruble zone. It was the first post-Soviet country to adopt a Western-style civil code, a modern legal and regulatory framework, to liberalize prices, to privatize industry, to open the door to foreign civic organizations, and to undertake electoral reform. It was the first member state of the CIS to join the World Trade Organization. However, Kyrgyzstan's limited resources constrained its progress. By the late 1990s the International Monetary Fund began to impose limits on Kyrgyzstan's sovereign borrowing. The luster of Kyrgyzstan's reputation as the "island of democracy" in Central Asia began to fade. ${ }^{22}$

Corruption and favoritism by the leaders of the government led to intense criticism of the Akaev government and eventually to the ouster of Askar Akaev in the so-called "Tulip Revolution" in March 2005..$^{23}$ A former Prime Minister, Kurmanbek Bakiev, set a course for political renewal, but Kyrgyzstan's fractious internal politics led to scandals and internal divisions. Bakiev found that Kyrgyzstan was dependent upon foreign assistance for economic help and security protection. Bakiev also found that foreign influence often pushed in opposing directions. Rather than choose an Eastern bias over a Western orientation, or vice versa, the Kyrgyzstan government sought to support both. Russian military forces were allowed to locate at the Kant airbase not far from Bishkek, and U.S. forces were allowed to be stationed at the Manas Ganci airbase on the other side of Bishkek. Kyrgyzstan's East-West formula was balanced only in the sense that it represented a dynamic tension between two continually contending influences on the Kyrgyz government. This tension continues to be the most salient feature of Kyrgyzstan's foreign policy.

The announcement by Kyrgyz President Kurmanbek Bakiev of the intention to close the Manas airbase in Kyrgyzstan gave new urgency to the task of assuring safe and reliable transport corridors for Afghanistan's normalization. Bakiev made the announcement of the base closure on 3 February 2009 while he was in Mos-

22 See Eugene Huskey, "An Economy of Authoritarianism? Askar Akaev and Presidential Leadership in Kyrgyzstan," in Power and Change in Central Asia, ed. Sally N. Cummings (London: Routledge, 2002), 74-96.

23 Erica Marat, The Tulip Revolution: Kyrgyzstan One Year After, March 15, 2005-March 24, 2006 (Washington: Jamestown Foundation, 2006). 
cow negotiating a foreign aid package for Kyrgyzstan with the Russian government. On the following day the Kyrgyz government submitted three government decrees regarding the Russian aid program to the Kyrgyz parliament for ratification at the same time as it submitted the decree on the base closure. In accordance with the military agreement originally signed in December 2001, the abrogation of the treaty could take effect as soon as 180 days after the decree was signed by the parliament. A commanding portion of the seats in the Kyrgyz parliament are held by a distinctly pro-president party, $A k$ jol, leaving little doubt that the parliament would present few obstacles to the presidential decree.

\section{Regional Cooperation in South and Central Asia}

Increased engagement on the part of the Central Asian countries in Afghanistan's normalization is by no means a new idea. Reflecting on the past experiences of the countries offers insight into their motivations in foreign policy. In the 1990s, the political leaders of the Central Asian states repeatedly appealed for international help in countering the growing threat of insurgency in the region resulting from the rise of the Taliban in Afghanistan. Following the 11 September 2001 attacks, the Central Asian countries were quick to endorse the international coalition that was assembled to sweep the Taliban from power and eliminate terrorist encampments in Afghanistan. Central Asian political leaders repeatedly and consistently called for more effective efforts to normalize the situation in Afghanistan, particularly with respect to countering insurgency and drug trafficking. Uzbekistan President Islam Karimov stepped forward at the April 2008 NATO Summit in Bucharest, calling for greater cooperation, pledging that "Uzbekistan stands ready to discuss and sign with NATO the Agreement on providing for a corridor and transit through its territory to deliver the non-military cargos through the border junction Termez-Khayraton, practically the sole railway connection with Afghanistan.",24

In the context of increased concern over the vulnerability of Afghanistan's resupply routes in early 2009, all the Central Asian countries as well as Azerbaijan, Georgia, and Russia offered assurances of unimpeded transport rights for "nonlethal" support supplies bound for Afghanistan. Kyrgyzstan President Bakiev announced that the closing of the Manas base would not affect the movement of nonmilitary cargo, to which Kyrgyzstan would remain open. Russian Foreign Minister Sergei Lavrov stated just a short time following Bakiev's announcement of the base closure that Russia had adopted an accelerated process to allow for the shipment of non-lethal goods through Russian territory. ${ }^{25}$

24 Address by President Islam Karimov at the NATO Summit in Bucharest (4 April 2008); available at http://mfa.uz/eng/press_and_media_service/news_and_events/040408e_2.mgr.

25 Ellen Barry, "U.S. Can Ship Afghan Aid Through Russia, Kremlin Says," The New York Times (7 February 2009). 
The Eurasian and Central Asian countries are no doubt motivated by a mixture of public spirit and self-interest. All of the countries share with ISAF and OEF forces the goal of neutralizing the threat from Al Qaeda, repelling insurgent movements, and returning Afghanistan to a state resembling normalcy. Indeed, the Central Asian countries have more at stake in the struggle against insurrectionist terrorism than do the European and American states. The Central Asian countries of Kyrgyzstan, Tajikistan, and Uzbekistan were the first victims of insurgent activity emanating from Afghanistan in 1997 and $1998 .^{26}$ If the international community fails to address the dangers of continued instability and failed governance in Afghanistan, these countries will be on the front lines of conflict with new insurgency and extremism.

As the Central Asian countries look forward, they perceive a set of risks and opportunities that in certain ways contradict one another, and are at variance with the perceptions of the Western countries. The states in Central Asia share common goals with NATO and OEF. Common goals are always the foundation of close cooperation. At the same time, however, shared goals do not necessarily assure joint action. The Central Asian states have reasons for pursuing their common goals in ways that are in some respects divergent from one another and their partners from outside the region. The divergence of methods may explain to some extent why some Central Asian states have a history of foreign policies that seems to be characterized by vacillation, zigzags, and reversals.

The political dimensions of Afghanistan's northern resupply routes are important for three reasons. First, cooperation involves the realistic, sober assessment of self-interest and common goals that are limited, voluntary, and practical. Second, commitments to cooperate can be reversed. Cooperation in practice involves relying on the continued activity of partners who themselves may be running a risk of detrimental reliance. Obviously, if a trusting cooperator runs a risk and the situation changes, the cooperator may be left in a situation that requires bearing an unexpected burden. Third, cooperation necessarily involves mutual understanding regarding specific, particular lines of action. But it does not entail complete agreement about the trajectories those lines follow. For these reasons, even when all agree that cooperation is important, and all parties are thus motivated to cooperate, it leaves questions as to whether cooperation can be expected to be durable or whether commitments will be reversed.

Are Commitments Reversible?

The case of the closure of Uzbekistan's Khanabad-Karshi airbase in 2005 and Kyrgyzstan's decision in February 2009 to close the Manas airbase provide insight

26 Gregory Gleason, "The Politics of Counterinsurgency in Central Asia," Problems of PostCommunism 48:2 (2002): 2-14. 
into the factors behind political commitment in the Central Asian context. The Manas airbase has played an important role in the deployment of coalition forces in Afghanistan. The utility of the Manas base increased substantially after the Khanabad-Karshi airbase located in neighboring Uzbekistan was closed following disputes with the Uzbek government. ${ }^{27}$ All U.S. troops left the base, and the logistical facilities at Khanabad-Karshi were returned to the Uzbek government in late 2005. In other countries of Central Asia, some military operations continued to be sustained through the use of military facilities on an ad hoc basis in Tajikistan and Turkmenistan. Some German troop operations continued to be supplied from the Khanabad-Karshi base, which is contiguous to the northern part of Afghanistan.

\section{Are Commitments Durable?}

One way to approach this question is to ask, "Are common lines of action sufficient grounds for cooperation?" The answer may depend on calculations of risk and the future scenarios that people expect as likely outcomes. All agree that the "Fate of Afghanistan" is a weighty subject. It is for this reason that ISAF and U.S. soldiers and aid workers are risking their lives and their countries' wealth to achieve a victory they believe to be attainable. Yet, from the perspective of the Central Asian capitals, it is easy to see the same objectives, adhere to roughly the same lines of action, and yet be fixed on a very different set of scenarios.

Some Central Asian analysts view the Karzai government as politically illegitimate, widely unpopular, and fundamentally incapable of spurring national consolidation. These analysts view Afghanistan as not engaged in a civil war, but rather essentially involved in an undeclared war with Pakistan's ungoverned territories. Afghanistan is divided by deep fissures along regional and ethno-cultural lines among the Hazaras, Tajiks, Pashtun, Uzbeks, and other peoples. The view of certain observers from the region is that in the eight years of fighting since $9 / 11$, the foreign forces have done much, but they have not brought calm, development, or even a solution to the Afghan narcotics problem.

These conditions lead these analysts to look forward, expecting that U.S./ ISAF forces will continue to remain embroiled in Afghanistan for a period of time, but that they will ultimately disengage without anything more substantial than a temporary cease-fire among the competing Afghan Taliban factions. Analysts who see the situation this way are apt to prepare for the next steps in the Afghanistan situation quite differently than those who confidently expect victory. The skeptical planners who fear that the Karzai government-or its successor-will fragment and Afghanistan will descend into disorder reminiscent of the events of 1992-94

27 See Daly, et al., Anatomy of a Crisis: U.S.-Uzbekistan Relations, 2001-2005. Also see Gregory Gleason, "The Uzbek Expulsion of U.S. Forces and Realignment in Central Asia," Problems of Post-Communism 53: 2 (2006): 49-60. 
are preparing for a different future than those who anticipate stability and continuity. No matter how profoundly unwelcome these outcomes are in some circles, there are nevertheless coldly anticipated. For Western partners to make calculations that fail to take these scenarios into account would be irresponsible to all the countries so directly affected by events in Afghanistan. What the Central Asian states plan for, how the transport networks function, and how the Western forces either do or do not enjoy support from the Central Asian countries will affect the outcome of the war.

\section{“Reset” and Russian Policy}

Russia is not merely another country in the Eurasian region. It is a country that previously held a dominant position and continues to have aspirations of regaining a position of unchallenged preeminence in the region. As such, Russian foreign policy has been and can be expected to remain a major factor in the foreign policy of the Central Asian states. There are many other factors that influence the decision making of states in Central Asia - the rising influence of China, the threat of insurgency and insurrection, the pressures created by volatile energy markets, the conflicts between Central Asian states over the water-and-energy nexus, migration, and many others. But in the foreign policy calculations of the states in the region, these factors typically do not play an independent role, but rather only have meaning in the context of Russia's policy toward the post-Soviet "South."

"Afghanistan Syndrome" is a seldom discussed but defining characteristic of Russian foreign policy. The failure of the Soviet military occupation of Afghanistan from its initiation in December 1979 under Leonid Brezhnev until the withdrawal under duress in 1989 under Mikhail Gorbachev framed an experience that has left a bitter residue in the minds of Russia's political elite. The course the Afghan war has taken has altered the Russian calculations of the long-term implications of Russia's association with Afghanistan. Humiliation at the failure of the Soviet adventure in Afghanistan has fueled resentment at the U.S. for its role in supporting Afghanistan's national independence in the 1980s and in expeditionary normalization after 9/11. The Russian political elite was scarred by the events on the national scale, if not from their own personal experiences in Afghanistan. They began to see Afghanistan, using the words of Boris Gromov (the Soviet General who commanded the forces leaving Afghanistan in 1989 and now an influential Moscow oblast governor), as the "graveyard of empires," a place from which no one returns.

There is no enthusiasm in Russia for any direct involvement in Afghanistan. At the same time, there is a strong commitment to not leave the fate of Afghanistan up to others. The U.S.-ISAF coalition in Afghanistan is generally viewed as destined to fail regardless of the level of expenditure of blood and treasure. The events of 11 September 2001 were followed in Russia by a realistic assessment 
that the U.S. would have to respond, but Russia's leaders anticipated having a more direct role, most particularly in the coordination of the Central Asian republics, where Russia saw itself as a benign imperial presence. Bush Administration officials never dignified such an idea with even a moment's consideration. While the proposal was not parried in any official form, it was something that remained in the minds of the Russian analysts. Nevertheless, Russian interlocutors were excluded from discussions and direct negotiations with the Central Asian states. All the states in the region agreed with alacrity to overflight arrangements with the U.S. without any interposition from Russia. Base arrangements were hastily arranged by several states in Central Asia who saw the U.S. as stepping in to protect their interests against the insurgent groups that were spawning in Afghanistan's disarray.

The U.S. presence in the Central Asian countries immediately provoked ire among the Cold Warriors among the Russian political elite. Criticism of Putin's unwillingness to step forward to protest America's presence led to his statement that it was "no tragedy" that America had risen to the occasion of a threat to its and the region's security interests. George W. Bush assured Moscow that the American presence was intended to be temporary. But with the increasingly complicated and drawn-out operation in Afghanistan, the onset of the Iraq war, the policy of the rendition of terrorist suspects, and the legalistic hair-splitting on the treatment of detained prisoners, the United States' image suffered dramatically. Putin labeled the U.S. war in Iraq "as a historical mistake." Russian politicians came to see the situation differently, not exactly out of schadenfreude but out of a traditional realist sense that if America was a competitor (even if not an enemy), whatever weakened the competitor was to Russia's benefit. Without saying it quite so bluntly, some Russian analysts began to see it as a positive that the U.S. was being drawn into an expensive war that would lead to overstretching America's resources and capacities. Russian nationalist politicians and analysts increasingly came to see U.S. policy as an opportunity to goad America into squandering its resources in favor of ideological or value-driven goals of democracy promotion, while Russia would fall back on its tradition of realistic pragmatism, repackaging its approach to the Central Asian and Caucasus states.

Against this backdrop, a policy emerged with respect to Afghanistan in which the Russians are loathe to enter themselves but unwilling to leave the resolution of the situation up to others. Obstructionism is immeasurably easier than construction. Where it is nowhere explicitly expressed in the foreign policy strategy documents, the Russian position has shifted to a "slow walk" on issues that it wants to stay on the record as supporting (such as pressuring Iran to abandon uranium enrichment) and to confrontational exercises of force, such as that which culminated in the Russo-Georgian war. Russia is trying to position itself with respect to a series of emerging challenges, including the decline of its natural gas and oil indus- 
try that it is trying to bring under closer government control; the growth of China and India, which are closer to Russia's anticipations and fears than they are to those in Europe and the U.S.; and the use of energy resources to manipulate Russia's Western commercial partners into foreign policies that will split the traditional Euro-Atlantic partnership in favor of a new broader security framework in which the U.S. plays a largely marginalized role in terms of voting influence and pride of position. Russia has also redoubled its efforts to stanch the continued sentiment in favor of the eastward expansion of NATO, drawing a line at Ukraine and sponsoring a massive public relations campaign that relied on the relative press freedom in Ukraine to try to capture public attention against splitting families and customs.

The Russian Foreign Policy strategic plan that emerged in 1993 made no reference to Afghanistan. The 2000 Foreign Policy Strategic plan that was introduced with the new Putin leadership made only vague references to South Asia. The 2008 Foreign Policy Strategic plan that ushered in the Medvedev leadership was equally vague. Yet, despite all this vagueness, Russia has taken specific steps. Russian President Dmitri Medvedev's conciliatory tone in the meeting with President Obama in Moscow on 8 June 2009 was intended to communicate a willingness to work collaboratively with American leaders on a range of issues, including Afghanistan. The meeting resulted in a communiqué in which both countries pledged to "make active use of the transit route through the territory of the Russian Federation for deliveries of property and equipment for the needs of the international forces operating in Afghanistan," making it clear that the Russian leaders were seeking to shape a cooperative response to the international coalition's efforts to normalize and reconstruct Afghanistan. This was a show of cooperation on the Afghanistan issue that was withheld until it was apparent that Russia was not consenting in absentia but was present as a party to the agreement on behalf of the other Eurasian countries.

\section{The Fate of Afghanistan}

The Obama Administration's strategy represents an unwavering U.S. commitment to the solution of the Afghanistan problem. The strategy straightforwardly states that "the core goal of the U.S. must be to disrupt, dismantle, and defeat Al Qaeda and its safe havens in Pakistan, and to prevent their return to Pakistan or Afghanistan." ${ }^{, 2}$ From the point of view of foreign policy, what is deterred with this approach may be more important than what is achieved. If the U.S. chooses or even indicates that it is considering an option to summarily withdraw from Afghanistan as a result of a calculation that the cost of continuing is too high, the objectives are

${ }^{28}$ See the "White Paper of the Interagency Policy Group's Report on U.S. Policy toward Afghanistan and Pakistan." 
too impractical, or the Karzai government is too corrupt, too incapable, or too infiltrated by Taliban opponents to carry out the job - or if the U.S. is too soured as a result of its experience in Iraq, or any number of other reasons - the U.S. runs the risk of igniting an implosion in which the insurgents would be emboldened to seize the opportunity to grasp power. In this scenario, Afghanistan's neighbors would be left on the country's periphery, vulnerable to the blow-back from the collapse of the Afghan government. There would be little to prevent a tragic replay of the winner-take-all competition that culminated in the 1994 resurgence of Taliban barbarism. If the U.S. and ISAF were to suddenly retreat, it may be speculated, the results would likely be so horrific that the U.S. and the European countries would not be able to withstand the moral opprobrium of sustained withdrawal. The retreat would be a temporary one.

If the commitment is to "stay the course," the question then becomes, "How long a course is it, and what would define a conclusion of the mission?" The simplest definition is the destruction of Al Qaeda. But even the simple goal to destroy Al Qaeda may imply many different things. One interpretation is to target and destroy Al Qaeda from a safe distance, for instance with unmanned aircraft. The complete elimination of Al Qaeda from a safe distance might be technically possible, but it runs the risk of producing and magnifying its own resistance in the process.

Another definition of success is the rebuilding of Afghanistan. In present circumstances this is not simple nation building, but armed nation building. This complex definition will require quite a lot of broad consensus before it is easily operationalized. The complete resuscitation of Afghan society through widespread nation building might stabilize the country such that Al Qaeda attenuates naturally. But basing a strategy on a race pitting builders against destroyers is inherently risky. In most circumstances the latter always have an advantage.

Under this second scenario, the "others"- the surrounding countries, their security agencies, the intersecting sectarian communities, the commercial interests, and so on-would be the first beneficiaries of the successful stabilization of Afghanistan. It is these "others" who may hold the key to naturally stepping in to take advantage of the markets and cultural influences, to pressuring insurgent forces, and to isolating and neutralizing the impetus of Taliban extremism. But these others also have at their disposal ways to exploit vulnerabilities and capitalize on disorder. These may be pivotal parties in the outcome if, as some believe, "Without security, stability, and cooperation from Afghanistan's neighbors, reconciliation will not occur." ${ }^{, 2}$ Afghanistan's northern neighbors have a role to play in

29 Mohammad Masoom Stanekzai, "Thwarting Afghanistan's Insurgency: A Pragmatic Approach toward Peace and Reconciliation," USIP Special Report (September 2008); available at www.usip.org/pubs/specialreports/sr212.html. 
this scenario that is not without its own risks. If the Central Asian and the Caucasus states are to become more active, they can be more productive in contributing to regional stabilization and normalization. At the same time, if they become more active, they necessarily can be expected to be more influential. The substantial benefits of the elaboration of a successful set of resupply relationships through the countries to the north of Afghanistan should be seen in this light.

Hence, both by necessity and by choice, there is a need for insight into the political dimensions of the issues related to Afghanistan's resupply routes. The PfP Consortium can play a valuable role here. The PfP Consortium - as the only organization that unites all of the Central Asian and Eurasian countries in developing capacity, standards, and competence - is uniquely positioned to make a contribution to help meet the challenge of promoting policies and practices in the Eurasian countries that can promote the success of the NDN. 


\section{Bibliography}

Address by President Islam Karimov at the NATO Summit in Bucharest., 2008.

Afghanistan: New U.S. Administration, New Directions In Asia Briefing. Kabul/Washington/Brussels: International Crisis Group, 2009.

Akbarzadeh, Shahram. Uzbekistan and the United States: Authoritarianism, Islamism and Washington's Security Agenda. London: Zed Books, 2005.

Anceschi, Luca. Positive Neutrality: The Role of Foreign Policy in the Consolidation of the Turkmen Regime (1992-2005). Vol. Ph.D. Thesis. Melbourne, Australia: La Trobe University, 2006.

Barry, Ellen. "U.S. Can Ship Afghan Aid Through Russia, Kremlin Says." The New York Times (2009).

Country Reports on Terrorism 2008. State Department, Office of the Coordinator for Counterterrorism, 2009.

Daly, John, Kurt Meppen, Vladimir Socor, and Frederick S. Starr. Anatomy of a Crisis: U.S.-Uzbekistan Relations, 2001-2005 In Silk Road Paper. Washington, D.C.: Central Asia-Caucasus Institute \& Silk Road Studies Program, Johns Hopkins University, 2006.

Dorronsoro, Gilles. Focus and Exit: An Alternative Strategy for the Afghan War. Washington, D.C.: Carnegie Endowment for International Peace, 2009.

Gleason, Gregory. "The Politics of Counterinsurgency in Central Asia." Problems of Post-Communism 48, no. 2 (2002): 2-14.

Gleason, Gregory. "The Uzbek Expulsion of U.S. Forces and Realignment in Central Asia." Problems of Post-Communism 53, no. 2 (2006): 49-60.

Gleason, Gregory. Kyrgyzstan's Multivector Foreign Policy Unravels In Commentary. Radio Free Europe/Radio Liberty, 2009.

Huskey, Eugene. "An Economy of Authoritarianism? Askar Akaev and Presidential Leadership in Kyrgyzstan." In Power and Change in Central Asia, 74-96. London: Routledge, 2002.

Jalali, Ali A.. "The Future of Afghanistan." Parameters 36, no. 1 (2006): 4-19 (quoted passage at p. 17).

Karimov, Islam. Uzbekistan on the Threshold of the Twenty-first Century. New York: St. Martin's Press, 1998.

Marat, Erica. The Tulip Revolution: Kyrgyzstan One Year After, March 15, 2005March 24, 2006. Washington: Jamestown Foundation, 2006.

McDermott, Roger. "Medvedev Expands the Northern Supply Route to Afghanistan." Eurasia Daily Monitor, Jamestown Foundation (2009).

McNabb, Duncan J.. Statement Before the House Appropriations Committee, Defense Subcommittee, on the State of the Command. USAF Commander, United States Transportation Command, 2009. 
New Deal on U.S. Air Base in Kyrgyzstan Signed into Law. Radio Free Europe/Radio Liberty, 2009.

Olcott, Martha Brill. "Central Asia's Catapult to Independence." Foreign Affairs 71, no. 3 (1992): 108-30.

Quinn-Judge, Paul. "The Risk to U.S. Supply Lines." The Wall Street Journal (2009).

Remarks by the President on a New Strategy for Afghanistan and Pakistan. Washington, D.C.: The White House, 2009.

Road Blocks: No Easy Routes into Afghanistan. The Economist (2009).

Special Report: U.S.-NATO, Facing the Reality of Risk in Pakistan. STRATFOR, 2009.

Stanekzai, Mohammad Masoom. Thwarting Afghanistan's Insurgency: A Pragmatic Approach toward Peace and Reconciliation In USIP Special Report. Vol. 53., 2008.

The Situation in Afghanistan and its Implications for International Peace and Security: Report of the Secretary-General. UN Security Council, 2008.

Tyson, Ann Scott. "Top Military Officer Urges Major Change in Afghanistan Strategy." Washington Post (2008): A01. 